Egyptian Journal of Aquatic Biology \& Fisheries

Zoology Department, Faculty of Science,

Ain Shams University, Cairo, Egypt.

ISSN $1110-6131$

Vol. 24(1): $13-29$ (2020)

www.ejabf.journals.ekb.eg

\title{
Industrial wastewater remediation using Hematite@Chitosan nanocomposite
}

\author{
Abdel Halim A. Saad ${ }^{1}$, Ahmed M. Azzam², Shaimaa T. El-Wakeel', \\ Bayaumy B. Mostafa ${ }^{2}$ and Mona B. Abd El-latif ${ }^{2^{*}}$ \\ 1- Department of Zoology, Faculty of Science, Ain-Shams University, Cairo, Egypt. \\ 2- Department of Environmental Researches, Theodor Bilharz Research Institute, Giza \\ Egypt. \\ 3- Department of Water Pollution Research, National Research Center, Egypt. \\ *Corresponding Author: monakhaleil@yahoo.com
}

\begin{tabular}{l} 
ARTICLE INF \\
Article History: \\
Received: Nov. 24, \\
Accepted: Dec. 29, \\
Online: Jan. 2020 \\
\hline Keywords: \\
Removal efficiency \\
Wastewater \\
Nanocomposite \\
Heavy metals \\
Hematite \\
Chitosan
\end{tabular}

ARTICLE INFO

Article History:

Accepted: Dec. 29, 2019

Keywords

Removal efficiency

Wastewater

Nanocomposite

Hematite

Chitosan

\begin{abstract}
Nowadays, the treatment of wastewater from toxic heavy metals is a long standing problem due to the industrial progress in the last years. The purpose of this study was to fabricate a novel hematite@chitosan core/organically shell nanocomposite (HCS) to remove $\mathrm{Pb}(\mathrm{II}), \mathrm{Cu}(\mathrm{II})$ and $\mathrm{Cd}(\mathrm{II})$ ions from industrial wastewater. The nanocomposite adsorbent was characterized by FE-SEM, TEM and FTIR resulting in formation of spherical dumb shaped particles with size range 40 to $80 \mathrm{~nm}$. The effect of many operating parameters such as $\mathrm{pH}$, metal ion concentration, adsorbent dosage and contact time on the removal of the toxic metal ions were investigated. The maximum removal efficacy for $\mathrm{Pb}$ (II), $\mathrm{Cu}$ (II) and $\mathrm{Cd}$ (II) was recorded at $\mathrm{pH} 6,4$ and 6.5, respectively. The equilibrium time was 60 , 60 and $30 \mathrm{~min}$, respectively while, the optimum efficiency was $94 \% 76 \%$ and $83 \%$ removal efficiencies for $\mathrm{Pb}$ (II), $\mathrm{Cu}$ (II) and $\mathrm{Cd}$ (II), respectively at initial concentration $10 \mathrm{mg} / \mathrm{l}$. The adsorption isotherms were better matched by the Langmuir model and the metal ions adsorption capacity were 129.8 , 63.2 and $69.9 \mathrm{mg} / \mathrm{g}$, for $\mathrm{Pb}$ (II), $\mathrm{Cu}$ (II) and Cd (II), respectively. Successive adsorption-desorption cycles occur by the adsorbent confirmed that HCS $\mathrm{NC}$ can be reused after recovery of ions by disodium salt of EDTA solution without significant capacity loss.
\end{abstract}

\section{INTRODUCTION}

The emission of heavy metals into the environment may be natural or anthropogenic (Taghipour and Mosaferi, 2013). Anthropogenic impacts including industrial discharge, domestic sewage, non-point source runoff and atmospheric precipitation are the main sources of toxic heavy metals that enter aquatic systems (Langston et al., 1999). Heavy metals are bio-accumulated in living organisms when taken up and stored more than softened (metabolized) or excreted (Gupta, 2013). Heavy metals toxicity has been reportable to be caused by completely different means; e.g., from contamination of drinking-water ( $\mathrm{Pb}$ pipes), high air concentrations close to emission sources (thus enter into soil) or from food chain. The heavy metals are poisonous as the result of the bio-accumulation (Lenntech, 2012; Gupta, 2013 \& Chibuike and Obiora, 2014). The Nile in Egypt facing major environmental problems associated with the dispersal or disposal of agricultural, industrial and urban wastes generated by human activities (Abdel-Mohsien and Mahmoud, 2015). 
The heavy metals in water connected most frequently to human toxicant are lead, cadmium and copper. They represent one necessary cluster of environmentally dangerous substances (Singh et al., 2011b). Lead is one among the foremost known toxic metals in drinking water moreover, its higher dose than permissible limit cause general metabolic toxic and enzyme suppressor (Gebrekidan and Samuel, 2011). Cadmium is very toxicant even in low concentrations and additionally future exposures to it cause renal failure (Khan et al., 2011). Copper is the necessary trace component however, high levels of it can cause brain harmful (Parveen et al., 2003). Moreover, its toxicity induces iron reduction, lipid peroxidation and damage of membranes (Zaidi et al., 2005).

The traditional procedures for removing heavy metal ions from aqueous streams include chemical precipitation, ion-exchange, adsorption, membrane filtration, coagulation \& flocculation, flotation, reverse osmosis, solvent extraction and electrochemical treatment technologies (Fu and Wang, 2011). The adsorption method has been put on the top as one of the main methods for toxic metal separation from wastewater/ water. Because of the reversible action of most adsorption techniques, the adsorbents can be renewed by suitable desorption techniques for many use (Pan et al., 2009) and multiple desorption techniques are of high efficiency, low cost and easily operated (Mishra et al., 1996). Some studies discussed removal of toxic metals with cheaper and economic adsorbents (Gupta et al., 2010; Gupta and Nayak, 2012\& Hassan et al., 2012). Modern researches proposed that several nanosized metal oxides (NMOs) show approving sorption to toxic metals in conditions of high selectivity and capacity, which could lead to intense separation of heavy metals to face progressively strict rules (Deliyanni et al., 2009). Between the useable adsorbents, NMOs, involving nano-sized ferric oxides, titanium oxides, aluminum oxides, manganese oxides, magnesium oxides and cerium oxides, which are listed as the hopeful ones for toxic heavy metals removal from liquid solutions (Agrawal and $\mathrm{Sahu}$, 2006). The hematite nanoparticles $\left(\mathrm{Fe}_{2} \mathrm{O}_{3}\right)$ is a magnetic NMOs which attract increasing attentions because they can be easily separated from water under a magnetic field (Mandavian and Mirrahimi, 2010). In addation, the magnetic NMOsbased composite adsorbents allowed easy isolation from aqueous solutions for recycling or regeneration after heavy metals adsorption (Zhao et al., 2011). Such facile separation is essential to improve the operation efficiency and reduce the cost during water/wastewater treatment.

Chitosan is a naturally occurring polysaccharide and it has excellent properties for the adsorption of heavy metal ions, mainly due to the presence of $-\mathrm{NH}_{2}$ group in chitosan matrix which mainly adsorbs metal ions in aqueous solution by ionexchange as well as by coordination linkage (Thinh et al., 2013 \& Huang et al., 2016). Nowadays, hybrid materials from chitosan and nanoparticles have been fabricated for toxic metals removal, which give effective adsorbent (Farzana and Meenakshi, 2015; Kandile et al., 2015; Ma et al., 2016\& Shahzad et al., 2017).

The aim of this work is to fabricate the hematite@chitosan (HCS) nanocomposite as a novel adsorbent and measuring its efficiency for removal of $\mathrm{Pb}^{2+}$, $\mathrm{Cu}^{2+}$ and $\mathrm{Cd}^{2+}$ from industrial wastewater. The reusability of the HCS was evaluated by recovery and multi-cyclic reuse.

\section{MATERIALS AND METHODS}

\section{Field Study}

In this study wastewater samples were collected from three localities in three Egyptian governorates; El-Menofia (Quesna Industrial Zone, El-Khadrawia and 
El-Sahl), El-Sharkia (Abbassa, Kafr El-Hosr and Bilbeis) and El-Fayium (Koum Oshim, Bahr Youssef and Bahr Hassan Wassef).

\section{Chitosan extraction}

In this work, the chitosan polymer was extracted from Penaeus Japonicus exoskeleton by using a procedure displayed by Abd El-Fattah et al. (2016). After washing of the fresh exoskeleton, it was dried under vacuum then, grinded to form powder. The powder was subjected to cycle from deproteinization, demineralization, discoloration and finally deacetylation. The technique was repeated to get high degree of deacetylation in chitosan polymer as shown in Scheme 1.

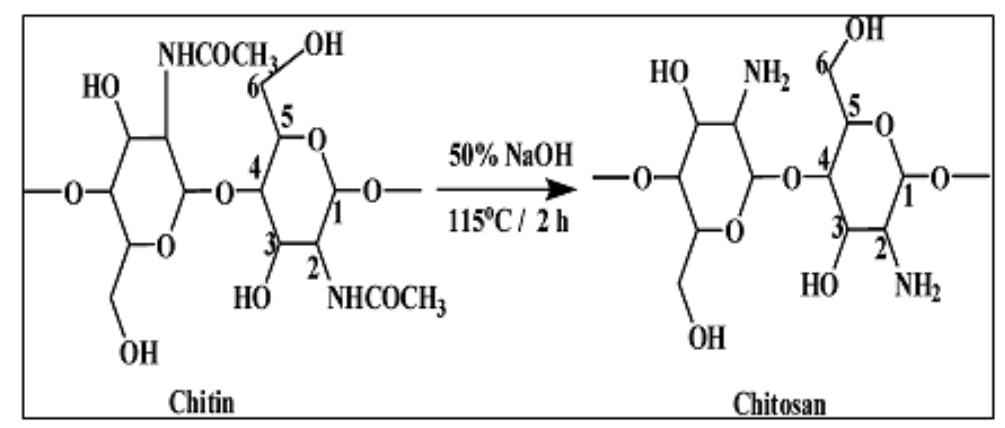

Scheme 1: Deacetylation of chitin to chitosan.

\section{Hematite nanoparticles synthesis}

Hematite nanoparticles (HNPs) was synthesized from $\mathrm{FeCl}_{3}$ according to Chen and Li (2010) \& Abdulkadir and Aliyu (2013) method to get a reddish brown powder from hematite nanoparticles.

\section{Preparation of hematite@ chitosan (HCS) core-shell nanocomposite}

The Nanocomposite was prepared according to Cabanas-Polo et al., 2015 as shown in scheme 2. To facilitate maximum coating of the hematite particles (core) with chitosan, the components were sonicated in an ultrasonic bath (Bandelin Sonorex, Germany).

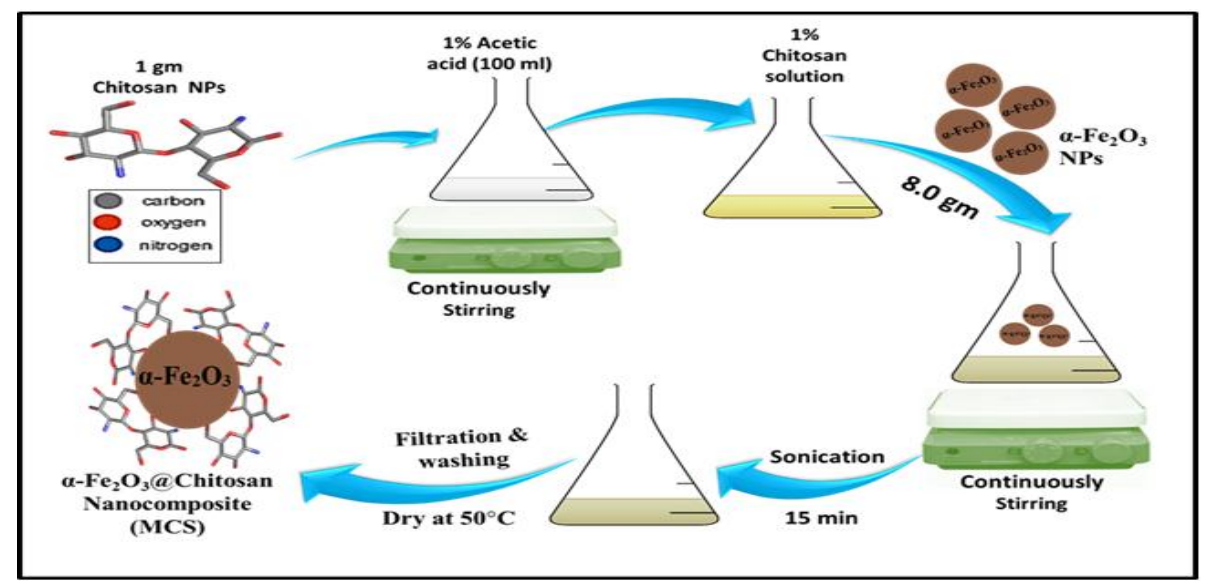

Scheme 2: Synthesis of hematite@ chitosan(HCS) core-shell nanocomposite.

\section{Hematite@ chitosan nanocomposite characterization}

The scanning electron microscopy (SEM), transmission electron microscope (TEM), Fourier Transform Infrared Spectroscopy (FTIR) and powder wide angel Xray diffraction spectrometry (WAXRD) measurements were used to characterize the fabricated HCS nanocomposite. The SEM (HITACHI S-4800, Japan) and TEM (HR TEM-JEOL 2100, Japan) were used to obtain morphologies and surface homogeneity 
of HCS nanocomposite. The FTIR spectrum was analyzed in the spectral range 4000 $-400 \mathrm{~cm}^{-1}$ wave numbers on an FTIR spectrometer (Thermo Scientific Nicolet iS 10 FTIR) via the $\mathrm{KBr}$ pressed disc method to display the functional groups of the adsorbent. The powder wide angel X-ray diffraction spectrometry (WAXRD) was performed by using Bruker D8 advance diffractometer with $\mathrm{Cu} \mathrm{K} \alpha$ radiation in the scanning range between 5 and $80^{\circ} 2 \theta(2$ theta) at a scanning rate of $4 \% \mathrm{~min}$.

\section{Experimental design}

In this work batch adsorption experiments were performed to study the behaviors of toxic heavy metals ions $\left(\mathrm{Pb}^{2+}, \mathrm{Cu}^{2+}\right.$ and $\left.\mathrm{Cd}^{2+}\right)$ on the synthesized HCS nanocomposite. The $\mathrm{Pb}^{2+}, \mathrm{Cu}^{2+}$ and $\mathrm{Cd}^{2+}$ sources were $\mathrm{PbCl}_{2}, \mathrm{Cu}_{2}\left(\mathrm{NO}_{3}\right)_{2}$ and $\mathrm{CdCl}_{2}$. In a typical experiment at room temperature a known amount $(0.5 \mathrm{~g} / \mathrm{L})$ of the nanocomposite adsorbent was added to a synthetic solution $(50 \mathrm{~mL})$ of each metal ion at $20 \mathrm{mg} / \mathrm{L}$. After that the solutions mixtures in the bottles were shaken in a rotary shaker (at $200 \mathrm{rpm}$ ) at different contact times. The adsorbent was removed by a 0.45 $\mu \mathrm{m}$ syringe filter and samples prepared for analysis. The concentrations of metal ions in the solution mixture were evaluated by using Inductively Coupled Plasma Optical Emission Spectroscopy (ICP-OES, Agilent 5100).

The adsorption capacity, $\mathrm{q}_{\mathrm{e}}(\mathrm{mg} / \mathrm{g})$, of metal ions and the removal efficiency at the equilibrium was calculated using following equations (Lasheen et al., 2016):

$q_{B}=\frac{\left(\mathrm{C}_{0}-\mathrm{C}_{\mathrm{e}}\right) \mathrm{V}}{\mathrm{W}} \times 100$

$\%$ Removal $=\frac{\mathrm{C}_{0-} \mathrm{C}_{\mathrm{e}}}{\mathrm{C}_{0}} \times 100$

Where, $q_{e}$ is the equilibrium adsorption capacity $(\mathrm{mg} / \mathrm{g}), \mathrm{C}_{0}$ and $\mathrm{C}_{\mathrm{e}}$ are the initial and equilibrium concentrations of heavy metals ions in the solution mixture $(\mathrm{mg} / \mathrm{L})$, respectively. V is the sample volume (L) and $\mathrm{W}$ is the mass of HCS adsorbent used (g).

The action of different parameters such as $\mathrm{pH}$, contact time, metal ion concentration and adsorbent dosage were studied to investigate the optimum adsorption efficiency. To identify the equilibrium contact time, $\mathrm{pH}$, dose and initial concentration; different contact times from 5 to $120 \mathrm{~min}, \mathrm{pH}$ range from 3 to 7 , different HCS NC dosage (0.05, 0.1, 0.5, 0.8 and $1.0 \mathrm{~g} / \mathrm{L})$ and different initial metal ions concentrations (of $\mathrm{Pb}(\mathrm{II}), \mathrm{Cu}$ (II) and $\mathrm{Cd}$ (II): 10, 20, 40, 80 and $160 \mathrm{mg} / \mathrm{L}$ of each metal) were used, while the other conditions remained the same as the typical experiment.

Adsorption kinetic experiments were investigated at optimum $\mathrm{pH}$ and dosage of the HCS adsorbent using different contact times. To predict the adsorption kinetic model, we fitted the experimental data with the two kinetics models. The pseudo firstorder equation detect adsorption in solid- liquid phase depend on the sorption capacity of solids. The pseudo-first order kinetic model (Chen and $\mathrm{Li}, 2010$ ) is given as:

$\log \left(q_{e}-q_{t}\right)=\log q_{e}-\frac{\mathbf{k}_{1} \mathrm{t}}{2.303}$

Where, $q_{e}$ and $q_{t}$ are the amounts of the heavy metal ions adsorbed on the HCS NC adsorbent in $\mathrm{mg} \mathrm{g}^{-1}$ at equilibrium and at time $\mathrm{t}$, respectively, while $\mathrm{K}_{1}$ is the firstorder adsorption constant in $\left(\mathrm{min}^{-1}\right)$.

The pseudo-second-order kinetic equation (Chen and $\mathrm{Li}, 2010)$ was applied to detect higher description of the kinetics is showed as: 


$$
\frac{1}{q_{t}}=\frac{1}{k_{2} q_{\mathrm{e}^{2}}}+\frac{t}{q_{e}}
$$

Where, $\mathrm{K}_{2}$ is the second-order adsorption constant in $(\mathrm{g} / \mathrm{mg}$. $\mathrm{min})$.

\section{Studying of the adsorption isotherms}

In the experiments of adsorption isotherm the metals ions solutions were at diverse initial concentrations $(10,20,40,80$, and $160 \mathrm{mg} / \mathrm{L})$ at room temperature and using the equilibrium $\mathrm{pH}$, contact time and dosage of the adsorbent. The data of the experiment were fitted in Freundlich 1906, Langmuir 1916 and Dubinin Kaganer Radushkevich (DKR) equations. The empirical Freundlich equation (Rahmani et al., 2010) describes the surface heterogeneity of HCS NC adsorbent and given as:

$$
\log q_{\mathrm{e}}=\log \mathrm{k}_{\mathrm{f}}+\frac{1}{\mathrm{n}} \log \mathrm{C}_{\mathrm{e}}
$$

The Langmuir equation (Rahmani et al., 2010) is depending on an assumption of a structurally homogeneous adsorbent, and given as:

$\frac{\mathrm{C}_{\mathrm{e}}}{\mathrm{q}_{\mathrm{e}}}=\frac{1}{\mathrm{bq}_{\max }}+\frac{\mathrm{C}_{e}}{\mathrm{q}_{\max }}$

Where, $q_{e}$ is the amount of heavy metal ions adsorbed per unit weight of adsorbent at a specified equilibrium (mg. $\left.\mathrm{g}^{-1}\right), \mathrm{C}_{\mathrm{e}}$ is the optimum concentration of the solution ( $\mathrm{mg}$ $\left.\mathrm{L}^{-1}\right), \mathrm{K}_{\mathrm{F}}$ is the Freundlich constant that represent the adsorption capacity $(\mathrm{mg} / \mathrm{g})$, and $\mathrm{n}$ is a constant, $\mathrm{q}_{\max }$ is the maximum adsorption at monolayer coverage $(\mathrm{mg} / \mathrm{g})$, and $\mathrm{b}$ is the Langmuir constant related to the energy of adsorption that quantitatively reflects the affinity of the binding sites $\left(\mathrm{mg}^{-1} \mathrm{~L}\right)$.

Dubinin Kaganer Radushkevich (DKR) isotherm model is used to describe adsorption on both homogeneous and heterogeneous surfaces. The general expression of the DKR isotherm (Febrianto et al., 2009) can be described by:

$\ln q=\ln q_{\max }-\beta \varepsilon^{2}$

Where, $\beta$ is the activity coefficient related to mean sorption energy $\left(\mathrm{mol}^{2} / \mathrm{kJ}^{2}\right)$, and $\varepsilon$ is the Polanyi potential,

The value of $\varepsilon$ can be calculated from Langmuir equation (Lasheen et al., 2016) as follow:

$\varepsilon=R T \operatorname{In}\left(1+\frac{1}{\mathrm{C}_{\mathrm{e}}}\right)$

Where, $\mathrm{R}$ is the ideal gas constant $(8.3145 \mathrm{~J} / \mathrm{mol} \mathrm{K}), \mathrm{T}$ is the absolute temperature (K).

\section{Reusability of HCS nanocomposites}

A solution of $20 \mathrm{mg} / \mathrm{L}$ metal ions were adsorbed using $0.5 \mathrm{mg}$ of HCS NC for $60 \mathrm{~min}$ and after that it was desorbed with adding $10 \mathrm{~mL}$ of $0.01 \mathrm{M}$ disodium salt of ethylenediaminetetraacetic acid ( $\mathrm{Na}_{2}$ EDTA) solution with continuous stirring for 60 min. The reusability was investigated by running four consecutive cycles of adsorption-desorption and the recovery efficiency, $\mathrm{R}(\%)$, of metal ions were calculated as follows (Jiang et al., 2014):

$R(\%)=\frac{c_{\text {des }}}{c_{\text {ads }}} \times 100$

Where, $C_{d e s}$ and $C_{a d s}$ are the amount of heavy metal ions desorbed into the aqueous solution and the amount of metal ions adsorbed onto the HCS nano-adsorbents (mg/L), respectively. 
Using the fabricated HCS NC in removal of metal ions from wastewater samples

Samples of wastewater were collected from three Egyptian industrials areas in El-Sharkia, El-Menofia and El-Fayium. The concentrations of three heavy metal ions $(\mathrm{Pb}$ (II), $\mathrm{Cu}$ (II) and $\mathrm{Cd}(\mathrm{II})$ ) were determined before and after application of HCS NC and removal efficiency percentage was calculated. Also, coexisting ions ( $\mathrm{Na}, \mathrm{Ca}$, and $\mathrm{K})$ were measured in untreated and treated wastewater samples.

\section{RESULTS AND DISCUSSION}

\section{Characteristic features of hematite@ chitosan core-shell nanocomposite (HCS)}

In the present study, the scanning electron microscope (SEM) picture of the hematite@chitosan nanocomposite (HCS NC) and its Bright-field image are showed in Fig.1A. Photograph studies of HCS NC by FE-SEM image revealed the hematite $\left(\alpha-\mathrm{Fe}_{2} \mathrm{O}_{3}\right)$ nanoparticles are mesocrystals characterized by a rough surface and primary crystalline domains (dumbbell-shaped) and these nanoparticles are joined together to form bundles of aggregates, which is agreed with the results of Rafi et al., 2015. The composite coatings chitosan based on $\alpha-\mathrm{Fe}_{2} \mathrm{O}_{3}$ mesocrystals are highly homogeneous coatings with well-distributed $\alpha-\mathrm{Fe}_{2} \mathrm{O}_{3}$ particles, this result can be confirmed by results showed by Cabanas-Polo et al., 2015. A spherical monodispersed $\alpha-\mathrm{Fe}_{2} \mathrm{O}_{3}$ nanoparticles were encapsulated into the spherical dumb shaped HCS nanocomposite, which is confirmed by results discussed by Singh et al., 2011a.

Fig.1B in the current study showed the transmission electron microscope (TEM) picture of the HCS NC. The particles of nanocomposites showed a rhombusshaped form in size from 40 to $80 \mathrm{~nm}$. They displayed different contrasts of $\alpha-\mathrm{Fe}_{2} \mathrm{O}_{3}$ $\&$ chitosan, the dark color represented for crystalline $\alpha-\mathrm{Fe}_{2} \mathrm{O}_{3}$ while the bright ones are associated with chitosan. This result of TEM image in our study is agreed and confirmed by results of Huang et al., 2010, which is an evident that HCS is synthesized successfully.

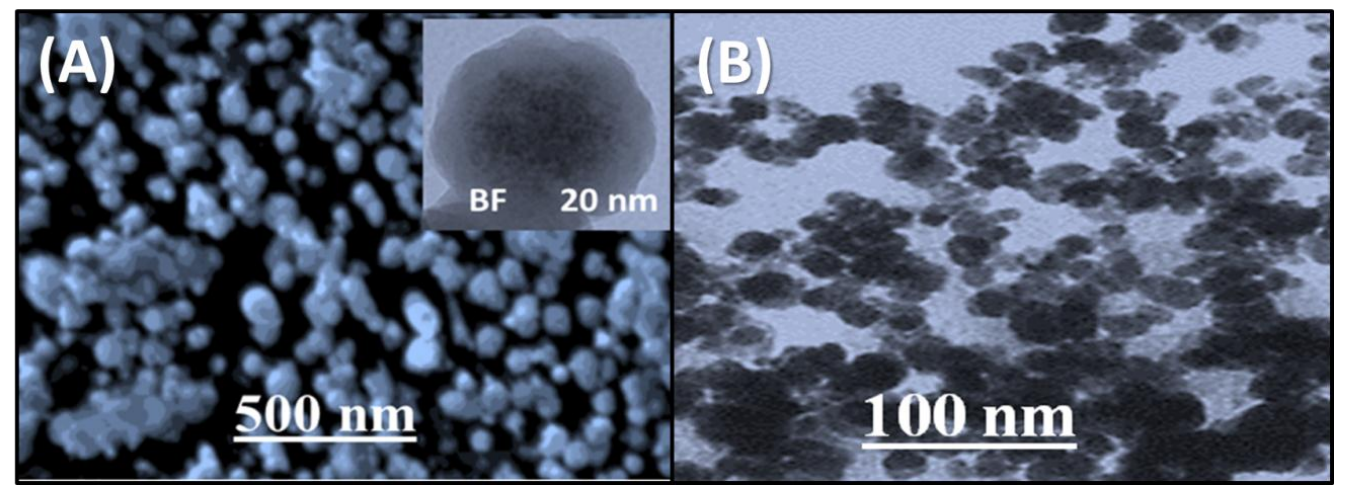

Fig. 1A: FE-SEM image and bright-field image \& B) TEM images of hematite@chitosan nanocomposite.

In the current study, all the peaks which are found in pure chitosan displayed in the FTIR spectrum of the hematite @ chitosan composite (Fig. 2), it is attributed to the presence of chitosan (CS) on the coating. This result confirmed by many other studies (Tian et al., 2003; Beidokhti et al., 2017; De Queiroz Antonino et al., 2017 \& Chen et al., 2019). In the present study, it is important to note the small shifting of the peaks at 3411 and 1598 (1598 is due to the characteristic peak of $\mathrm{NH}_{2}$ group in pure chitosan) $\mathrm{cm}^{-1}$ to 3375 and $1587 \mathrm{~cm}^{-1}$, respectively. According to Singh et al 
(2011a), this shifting of the peak around $1598 \mathrm{~cm}^{-1}$ indicates that the $\mathrm{NH}_{2}$ group of CS is involved on the assembling of the $\alpha-\mathrm{Fe}_{2} \mathrm{O}_{3}$. In the present study, the more intense bands that appear at 540 and $459 \mathrm{~cm}^{-1}$ in the Far-FTIR region of the $\alpha$ hematite/chitosan composite coating. The appearance of these two bands supports the presence of $\alpha-\mathrm{Fe}_{2} \mathrm{O}_{3}$ in the composite coating, which is attributed to the real success of the fabricated nanocomposite. This result agreed with Singh et al., 2011a.

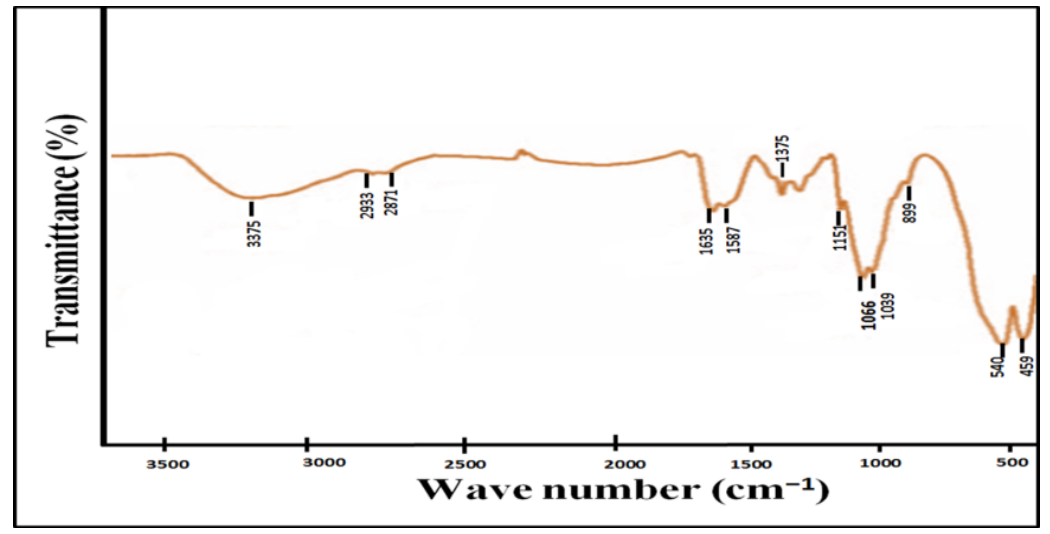

Fig. 2: FTIR spectrum of hematite@ chitosan nanocomposite.

In the present work, the X-ray powder diffraction (XRD) pattern of the HCS nanocomposite was showed in Fig.3. A small broad peak at $22.03^{\circ}$ was assigned to CS. The other diffraction peaks at $33.44^{0}, 35.94^{0}, 40.95^{\circ}, 49.55^{0}, 54.50^{\circ}, 57.50^{\circ}$, $63.20^{\circ}, 67.50^{\circ}$ and $74.50^{\circ}$ were assigned to the (012), (104), (110), (113), (024), (116), (122), (214) and (300) planes of $\mathrm{Fe}_{2} \mathrm{O}_{3}$ respectively, which revealed that the particles crystallized in hexagonal structures. The nanocomposite coating other diffraction peaks with lower intensity can be found. The XRD peaks were in good agreement with the cubic $\mathrm{Fe}_{2} \mathrm{O}_{3}$ showing the successful formation of the hematite@chitosan nanocomposite. This result is agreed with results showed by Huang et al., 2010 and Srivastava et al., 2010.

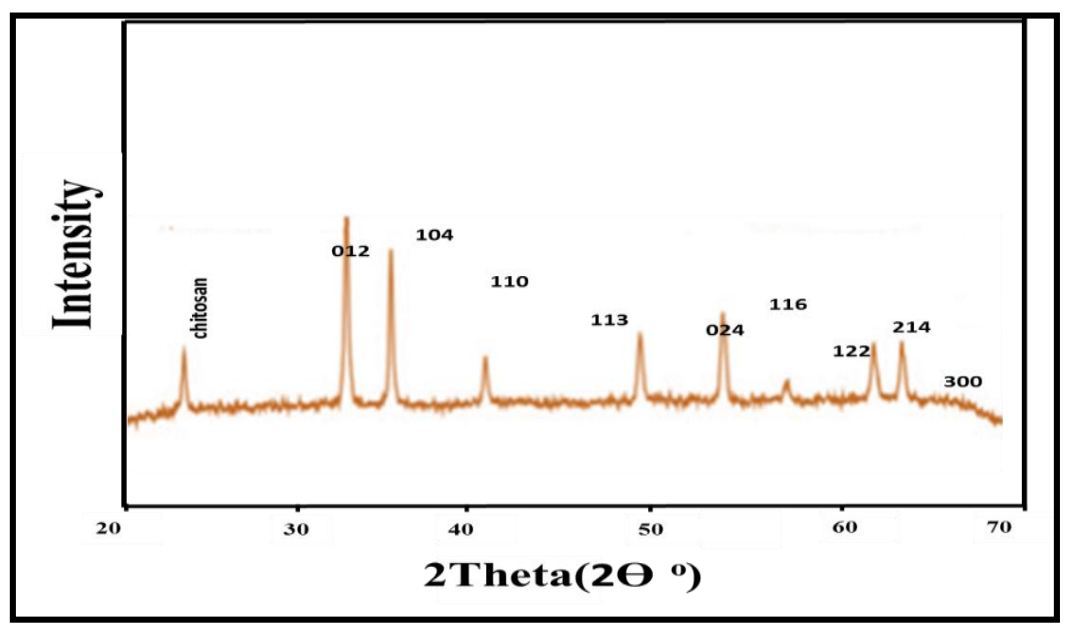

Fig. 3: The XRD pattern of hematite@ chitosan nanocomposite.

\section{Adsorption experiments Effect of $\mathbf{p H}$}

In the current work, the effect of $\mathrm{pH}$ was investigated in the removal of heavy metal ions from aqueous solution using the synthesized HCS NC adsorbent. The $\mathrm{pH}$ 
began from 3 as chitosan may be dissolved at $\mathrm{pH}$ less than 3 . The optimum removal efficiency for $\mathrm{Pb}$ (II) was $93 \%$ at $\mathrm{pH} 6$, while the optimum one for $\mathrm{Cd}$ (II) and $\mathrm{Cu}$ (II) were at $\mathrm{pH}$ of 6.5 and 4 , respectively (Fig. 4A). The maximum removal of $\mathrm{Cu}$ (II) occur at $\mathrm{pH} 0.4$, beyond $\mathrm{pH} 6$, the precipitate was formed for $\mathrm{Cu}$ (II) solution, this result is supported by results showed by Sun et al., 2006 \& Huang et al., 2012. In this result, in case of $\mathrm{Cd}(\mathrm{II})$ and $\mathrm{Pb}(\mathrm{II})$, the optimum removal occur at $\mathrm{pH} 6.5$ and 6 , respectively, it is clear that by increasing the $\mathrm{pH}$ parameter from 3 to 6 the adsorption capacity of $\mathrm{Pb}$ (II) and $\mathrm{Cd}(\mathrm{II})$ increases, after that decreases sharply with increasing $\mathrm{pH}$. Moreover, at $\mathrm{pH} 8$ and 8.5 , the precipitate was formed in $\mathrm{Cd}$ (II) and $\mathrm{Pb}$ (II) solutions respectively, this is confirmed by results of Huang et al., 2012. This results can be attributed to that at $\mathrm{pH}=2$, low acidic medium, protonation of amino groups of chitosan $\left(\mathrm{NH}^{3+}\right)$ was occurred, which can lead to decrease in adsorption capacity. But, by increasing $\mathrm{pH}$ the competition between toxic ions cations and protons decreased and the decreasing in the positive surface charge reduces the electrostatic repulsion between surface and metal ions. This conclusion is supported by results of Liu et al., 2010. The $\mathrm{pH}$ is an important parameter in the adsorption technique as a result of its role in the active sites of adsorbent (Liu et al., 2009).

\section{Effect of contact time}

The exposure time between adsorbate and adsorbent is a critical parameter in the adsorption of $\mathrm{Cd}$ (II), $\mathrm{Pb}$ (II), and $\mathrm{Cu}$ (II) using the prepared HCS NC (Fig. 4B). In this study, the adsorption of toxic ions increased with increasing the contact time till reached at steady state called equilibrium time. The equilibrium time was $60 \mathrm{~min}$ for $\mathrm{Pb}$ (II) and $\mathrm{Cu}(\mathrm{II})$ and $30 \mathrm{~min}$ for $\mathrm{Cd}(\mathrm{II})$. This result approved with Keshvardoostchokami et al. (2017) who used chitosan/ $\mathrm{Fe}_{2} \mathrm{O}_{3}$ nanocomposite in removal of nickel, cadmium and lead from aqueous solution. The prepared HCS NC in our study adsorbs toxic ions in the order $\mathrm{Pb}$ (II) $>\mathrm{Cd}$ (II) $>\mathrm{Cu}$ (II) which is in agreement with Broujeni et al., 2018.

\section{Effect of adsorbent dosage of HCS NC}

One of the critical parameters that have a strong effect on the adsorption capacity is the amount of the adsorbent. Form data of the present study, the adsorption of toxic ions was highly depended on the adsorbent dose, an optimum adsorbent amount is strongly needed to magnify the interactions between toxic metal ions and active sites of adsorbent in the solution. In the current work, the maximum uptake was recorded at very low amount, keeping the other parameters such as $\mathrm{pH}$, initial concentration, contact time constant, $92 \%$ of $\mathrm{Pb}$ (II) at $0.5 \mathrm{~g} / 1,84 \%$ of $\mathrm{Cd}(\mathrm{II})$ and $74 \%$ of $\mathrm{Cu}$ (II) removed at $0.8 \mathrm{~g} / \mathrm{l}$ (Fig.4C). This may be attributed to that the presence of more active sites on HCS at higher doses of adsorbent, which is confirmed by results of Laus and Fávere, 2011. From the current results, it can be concluded that, the adsorption of metals increased with increasing amount of the nanocomposite, this is agreed with result by Lasheen et al., 2014. In the present experiment, the removal percentage increases as the adsorbent doses increases, but further increasing in the concentrations results in a decreasing in removal efficiency. It can be concluded that, at lower adsorbent concentrations the increasing in the adsorbent doses provides more binding sites for metal ions adsorption. However, by the increasing in adsorbent doses and no change of the agitation speed may lead to some aggregation appeared in the system, therefore less binding sites for metal ions are available at higher dose of adsorbent. This conclusion is approved with results by Zhou et al., 2009. 


\section{Effect of initial metal ions concentration}

In this study, the effect of initial metal concentrations ions was investigated in the range of 10-160 $\mathrm{mg} / \mathrm{L}$. The maximum removal capacities were at the lowest initial concentration of metal ions, $94 \%, 83 \%$ and $76 \%$ removal capacities for $\mathrm{Pb}$ (II), $\mathrm{Cd}$ (II) and $\mathrm{Cu}(\mathrm{II})$, respectively for HCS (Fig.4D). It can be concluded that the removal capacities decreased with increasing the metal ions initial concentrations. This is due to increasing the metal ions concentration but, the adsorbent active sites were not increased correspondingly.This result confirmed by Han et al., 2006 and Dong et al., 2017.

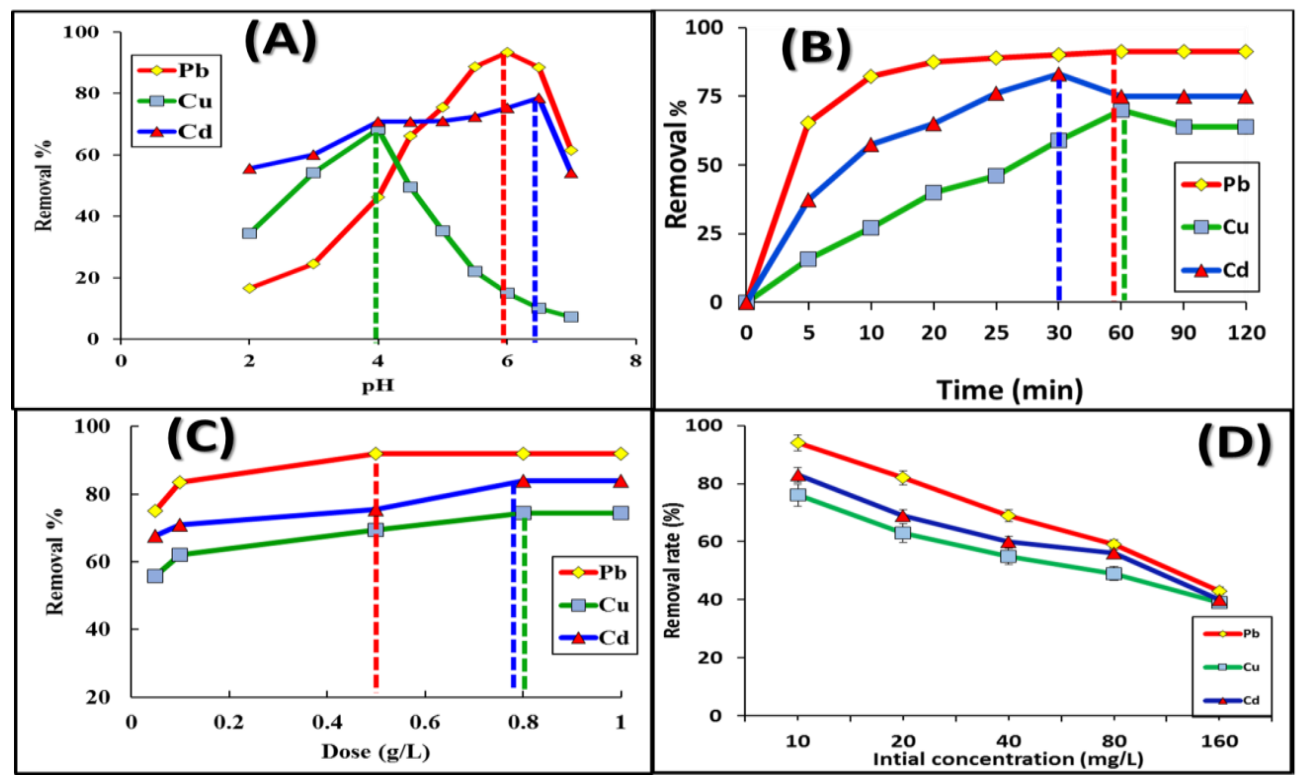

Fig. 4 A: Effect of pH; B: Effect of contact time; C) Effect of Absorbent dose, and D) Effect of initial concentration of heavy metals ions on removal rates by hematite@chitosan nanocomposite (shaking rate: $200 \mathrm{rpm}$ at room temperature).

\section{Adsorption equilibrium models Adsorption isotherm}

In the present study, Table 1, showed that the adsorptions procedure occurred on heterogeneous surfaces; assuming that many binding sites present on the adsorbent surface, which is agreed with the chemical structure of HCS NC according to Freundlich isotherm equation. Also, the current data proving highly binding chemisorption between toxic metal ions and HCS nanocomposite according to Regression coefficient $\left(R^{2}\right)$ values which were achieved at $1 / n$ values less than one, therefore the achieved high values of $R^{2}$ proved that the equilibrium data were fitting with the adsorption model (Fig. 5A). The current results is supported and agreed with Charpentier et al., they pointed to type of reaction according to $\mathrm{R}^{2}$ values (Charpentier et al., 2016) and Lin et al., according to $\mathrm{n}$ values (Lin et al., 2009).

In the present study, Fig. 5B showed the calculation of the $\mathrm{q}$ max values and $\mathrm{b}$ from the slope and intercept. The resulting data of Langmuir equation proved that these data were fitted to the Langmuir equation and the adsorption efficiencies of HCS nanocomposite was $129.8>69.9>63.2 \mathrm{mg} / \mathrm{g}$ for $\mathrm{Pb}(\mathrm{II}), \mathrm{Cd}(\mathrm{II})$, and $\mathrm{Cu}(\mathrm{II})$, respectively (Table 1). This current data according to Langmuir isotherm equation assumes the presence of monolayer of toxic ions cover out surface of the composite (physical adsorption) and there is no reaction between adsorbate and adsorbent, therefore, the saturation occurred, suggesting that the adsorbent surface has a definite number of sites of similar energy and each adsorbate ion is bind at a single finite site 
which is in agreement with results by Abou El Fadl, 2014. Also our results supported by Zhao et al. \& Chen and Wang; they achieved high adsorption efficiency and the equilibrium data was applied well by Langmuir model (Zhao et al., 2007\& Chen and Wang, 2008).

In the present experiment, the DKR isotherm model is considered as a semiempirical equation, by applying the data for HCS NC, the maximum adsorption capacity $\mathrm{q}_{\max }(\mathrm{mol} / \mathrm{g}$ ) was calculated (Fig. 5c). The values of $\varepsilon$ for the HCS NC in the current work were 12.9, 11.9 and $10.6 \mathrm{~kJ} / \mathrm{mol}$ for $\mathrm{Pb}(\mathrm{II}), \mathrm{Cd}(\mathrm{II})$ and $\mathrm{Cu}$ (II), respectively (Table 1), thus the adsorption is assumed by chemical ion-exchange. This result was agreed with result by Lasheen et al., 2014.

This is attributed to that $\varepsilon$ number is used for choose the mode of action between nanoadsorbent and metal ions during removal technique., if $\varepsilon$ is in the range of $8-16 \mathrm{~kJ} / \mathrm{mol}$, the adsorption is assumed by chemical ion-exchange, while at $\varepsilon$ less than $8 \mathrm{~kJ} / \mathrm{mol}$, the physical reaction represent the adsorption process (Hao et al., 2010).

Table 1: Isotherm models parameters for the adsorption of $\mathrm{Cu}(\mathrm{II}), \mathrm{Pb}(\mathrm{II})$ and $\mathrm{Cd}(\mathrm{II})$ by $\mathrm{HCS}$ nanocomposite.

\begin{tabular}{lccc}
\hline Freundlich isotherm parameters & $\mathbf{C u}(\mathbf{I I})$ & $\mathbf{P b}(\mathbf{I I})$ & $\mathbf{C d}(\mathbf{I I})$ \\
\hline $1 / \mathrm{n}$ & 0.38 & 0.32 & 0.34 \\
$\mathrm{~K}_{\mathrm{F}}(\mathrm{mg} / \mathrm{g})$ & 9.58 & 27.2 & 13.4 \\
$\mathrm{R}^{2}$ & 0.92 & 0.92 & 0.92 \\
\hline Langmauir isotherm parameters & $\mathbf{C u}(\mathbf{I I})$ & $\mathbf{P b}(\mathbf{I I})$ & $\mathbf{C d}(\mathbf{I I})$ \\
& & & \\
\hline $\mathrm{q}_{\max }(\mathrm{mg} / \mathrm{g})$ & 63.2 & 129.8 & 69.9 \\
$\mathrm{~b}(\mathrm{~L} / \mathrm{mg})$ & 0.05 & 0.8 & 0.07 \\
$\mathrm{R}^{2}$ & 0.99 & 0.99 & 0.99 \\
\hline DKR isotherm parameters & $\mathbf{C u}(\mathbf{I I})$ & $\mathbf{P b}(\mathbf{I I})$ & $\mathbf{C d}(\mathbf{I I})$ \\
& & & \\
\hline $\mathrm{q}_{\max }(\mathrm{mol} / \mathrm{g})$ & $2 \times 10^{3-}$ & $1.6 \times 10^{3-}$ & $1 \times 10^{3-}$ \\
$\varepsilon(\mathrm{KJ} / \mathrm{mol})$ & 10.6 & 12.9 & 11.9 \\
$\mathrm{R}^{2}$ & 0.92 & 0.96 & 0.95 \\
\hline
\end{tabular}

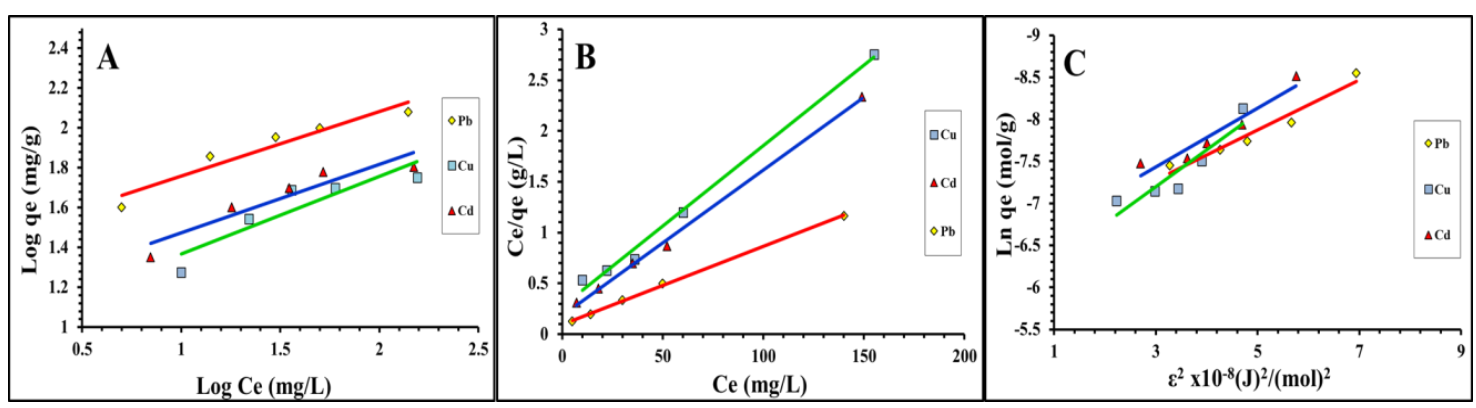

Fig. 5 A: Freundlich isotherm; B) Langmuir isotherm, and C) DKR isotherm plots for metals adsorption by HCS (absorbent dose: $0.5 \mathrm{~g} / \mathrm{l}$ for $\mathrm{Pb}$ and $0.8 \mathrm{~g} / \mathrm{l}$ for $\mathrm{Cu}$ and $\mathrm{Cd}$; $\mathrm{pH}$ value: 4, 6.5, 6 for $\mathrm{Cu}, \mathrm{Cd}$ and $\mathrm{Pb}$ respectively; initial concentration: $20 \mathrm{mg} / \mathrm{L}$; contact time: $30-60 \mathrm{~min}$, agitation time: $200 \mathrm{rpm})$.

\section{Adsorption kinetics}

In the present work, the data of first-order kinetic equation for the adsorption of metal ions $\left(\mathrm{Cu}^{2+}, \mathrm{Pb}^{2+}\right.$ and $\left.\mathrm{Cd}^{2+}\right)$ by $\mathrm{HCS}$ proved that the calculated $\mathrm{q}_{\mathrm{e}}$ value obtained by this model don't match with the experimental value (the experimental $q_{e}$ ) of firstorder model (Table 2 and Fig. 6) whereas, the calculated $\mathrm{q}_{\mathrm{e}}$ values are strongly agreed with the experimental data of this equation. However, $\mathrm{R}^{2}$ regression coefficient 
(correlation coefficient) of equation for the linear plots are very close to one therefore, by this way the reaction near to equilibrium and the adsorption process is chemisorption. This result was approved with the results of Shekhawat et al., 2017 and highly agreed with Lasheen et al., 2014 and Chen et al. (2019).

Table 2: Kinetic parameters for $\mathrm{Cd}$ (II), $\mathrm{Pb}$ (II) and $\mathrm{Cu}$ (II) adsorption by $\mathrm{HCS}$ nanocomposite at room temperature (adsorbent dose: $0.5 \mathrm{~g} / \mathrm{L}, \mathrm{pH}$ value: 5.5 , metals concentration: $20 \mathrm{mg} / \mathrm{L}$, contact time: 5-120 min, agitation speed: $200 \mathrm{rpm}$ ).

\begin{tabular}{lccc}
\hline Pseudo-first order & Cd(II) & Pb(II) & $\mathbf{C u}(\mathbf{I I})$ \\
\hline $\mathrm{q}_{\mathrm{e}}(\mathrm{mg} / \mathrm{g})$ (calculated) & 40.6 & 75.2 & 36.2 \\
$\mathrm{q}_{\mathrm{e}}(\mathrm{mg} / \mathrm{g})$ (experiment) & 13 & 10 & 29 \\
$\mathrm{~K}_{1}\left(\mathrm{~min}^{-1}\right)$ & 0.1 & 0.09 & 0.05 \\
$\mathrm{R}^{2}$ & 0.88 & 0.90 & 0.92 \\
\hline Pseudo-second order & & & \\
\hline $\mathrm{q}_{\mathrm{e}}(\mathrm{mg} / \mathrm{g})$ (calculated) & 40.6 & 75.2 & 36.2 \\
$\mathrm{q}_{\mathrm{e}}(\mathrm{mg} / \mathrm{g})$ (experiment) & 42.3 & 75.7 & 42.7 \\
$\mathrm{~K}_{2}(\mathrm{~g} / \mathrm{mg}$ min) & 0.14 & 0.02 & 0.002 \\
$\mathrm{R}^{2}$ & 0.99 & 0.99 & 0.99 \\
\hline
\end{tabular}

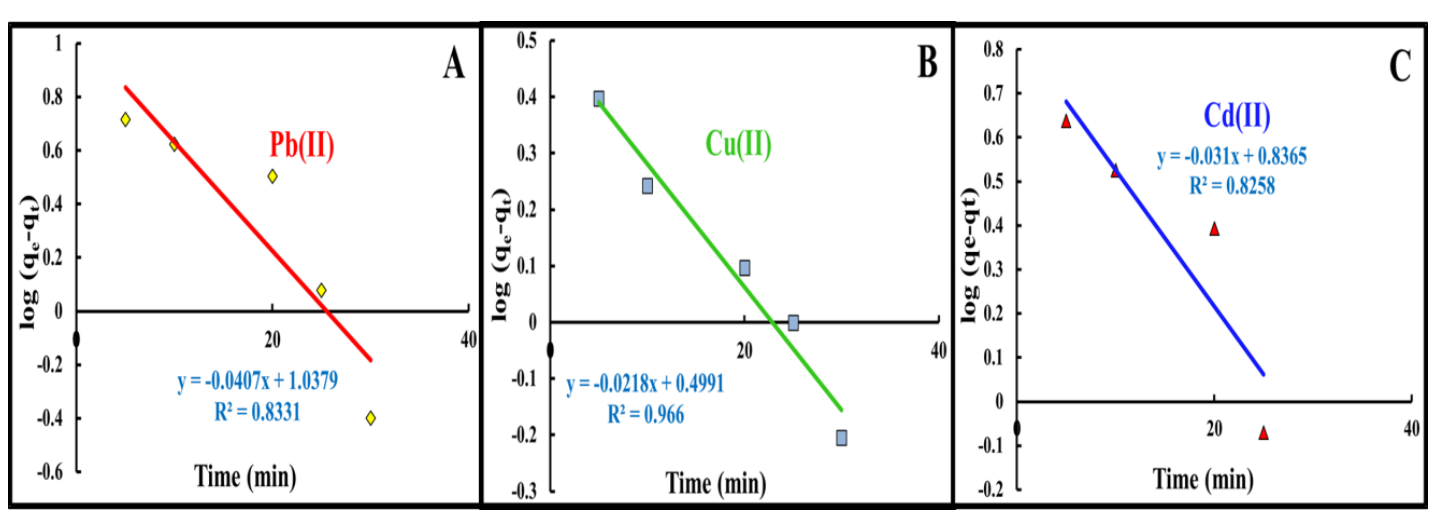

Fig. 6 A, B and C: Pseudo-first order sorption kinetics of metal ions ( $\mathrm{Pb}(\mathrm{II}), \mathrm{Cu}(\mathrm{II})$ and $\mathrm{Cd}(\mathrm{II})$ ) by HCS.

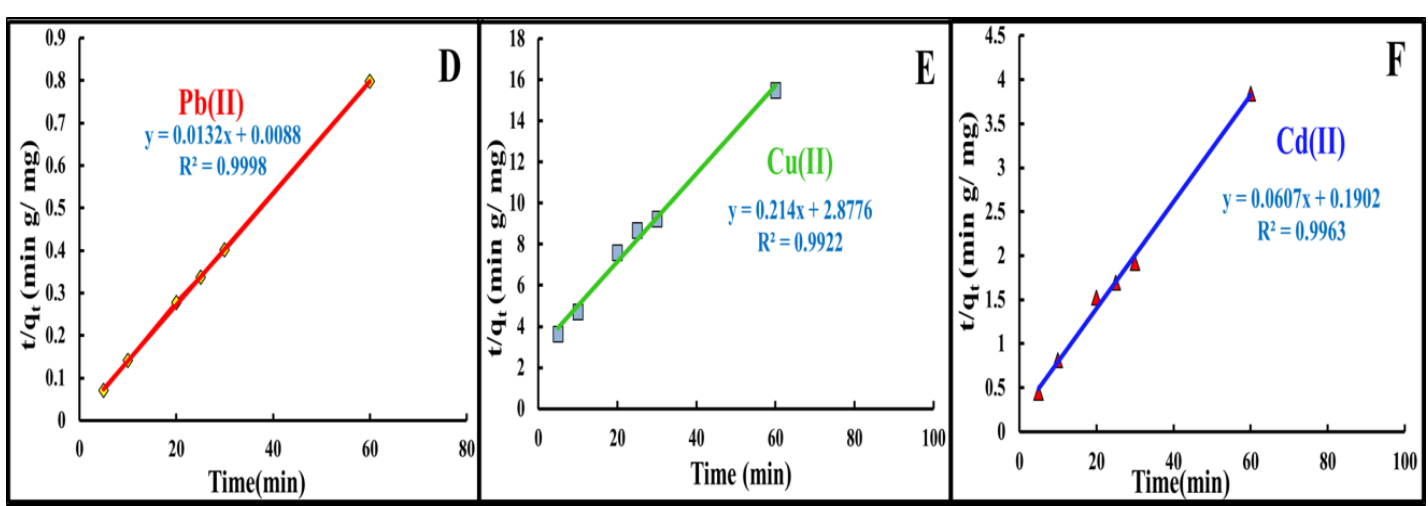

Fig. $6 \mathrm{D}, \mathrm{E}$ and F: Pseudo-second order sorption kinetics of metal ions (Pb (II), $\mathrm{Cu}$ (II) and $\mathrm{Cd}$ (II)) by HCS.

\section{Regeneration of metal ions and recycling of HCS NC}

For regeneration investigation and stability of nanoadsorbent, a number of cycles were checked. In the present work, the regeneration capacity of tested metal ions from HCS nanocomposite was investigated by using $0.01 \mathrm{M} \mathrm{Na}_{2}$ EDTA, no observed drop in adsorption capabilities for the tested metal ions even after 4 adsorption-desorption cycles, the capacities were $>98 \%$ for $\mathrm{Pb}(\mathrm{II}),>94 \%$ for $\mathrm{Cd}(\mathrm{II})$ and $>91 \%$ for $\mathrm{Cu}(\mathrm{II})$. Hence the regeneration capacity of HCS for three ions was 
fully regenerated with significant regeneration capacity during many cycles (Fig. 7). This result is supported by result of Chen et al., 2019, which the nanocomposite is almost fully regenerated.

It can be concluded that the synthesized HCS nanocomposite can act as a highly renewable and stable adsorbent for practical application and can satisfy the increasing need for the purification of water resources.

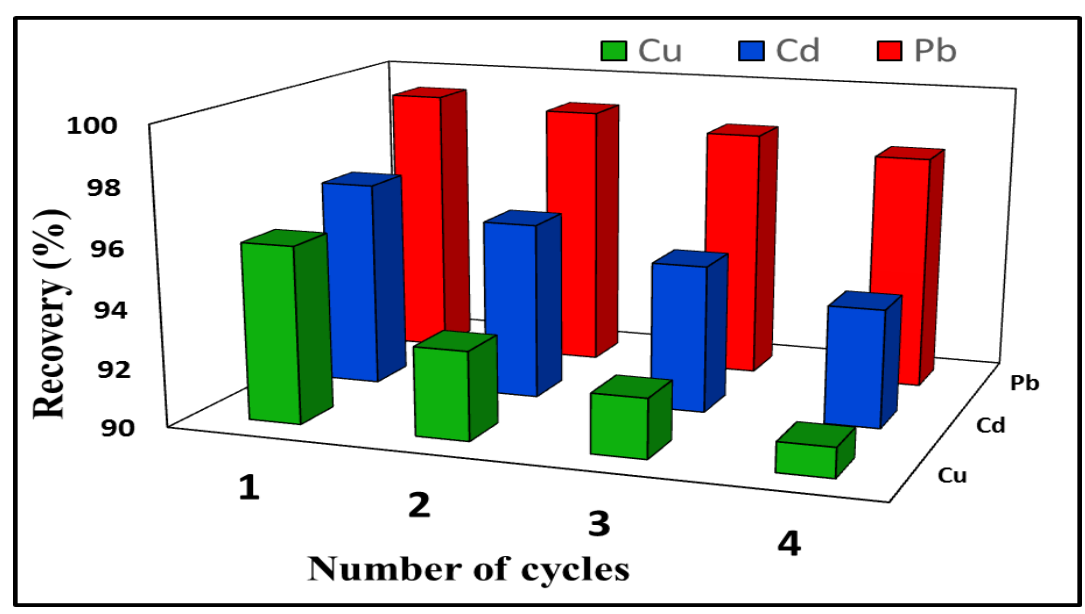

Fig. 7: Regeneration percentage of $\mathrm{HCS}$ nanocomposite for $\mathrm{Pb}(\mathrm{II}), \mathrm{Cd}(\mathrm{II})$ and $\mathrm{Cu}$ (II) during cyclic experiments (initial concentration of $20 \mathrm{mg} / \mathrm{L}$ at $\mathrm{pH} 4.0,6.0$ and 6.5 , respectively).

\section{Removal of metal ions from wastewater samples}

In this work, nine wastewater samples, from three governorates, were treated to determine the sorption performance of the synthesized HCS adsorbent. The results were shown in Table 3. The removal rates of toxic metals from the selected samples were treated under condition of $\mathrm{pH} 5.5,0.5 \mathrm{mg} / \mathrm{L}$ HCS NC, shaking time $1 \mathrm{~h}$ and room temperature. The removal rates of $\mathrm{HCS}$ for $\mathrm{Pb}$ (II), $\mathrm{Cd}(\mathrm{II})$ and $\mathrm{Cu}$ (II) were $>96.5 \%$ for $\mathrm{Pb}$ (II), $>95 \%$ for $\mathrm{Cd}$ (II) and $>89.9 \%$ for $\mathrm{Cu}$ (II) in the presence of coexisting ions ( $\mathrm{Na}, \mathrm{K}$ and $\mathrm{Ca}$ ) (Chiban et al., 2016). These proved that HCS NC showed highly strong effect in environmental remediation and wastewater treatment.

Table 3: Analysis of heavy metal ions and Coexisting ions in wastewater samples with HCS nanocomposite.

\begin{tabular}{|c|c|c|c|c|c|c|c|c|c|c|}
\hline \multirow{2}{*}{$\begin{array}{l}\text { Sample } \\
\text { source }\end{array}$} & \multirow[t]{2}{*}{ Site } & \multicolumn{3}{|c|}{ Heavy metals ion $\left(\mathrm{mg} \mathrm{L}^{-1}\right)$} & \multicolumn{3}{|c|}{ Coexisting ions $\left(\mathrm{mg} \mathrm{L}^{-1}\right)$} & \multicolumn{3}{|c|}{ Removal rate $(\%)$} \\
\hline & & $\mathrm{Cu}^{2+}$ & $\mathbf{P d}^{2+}$ & $\mathrm{Cd}^{2+}$ & $\mathrm{Na}^{+}$ & $\mathbf{K}^{+}$ & $\mathrm{Ca}^{2+}$ & $\mathrm{Cu}(\mathrm{II})$ & $\mathbf{P d}(\mathrm{II})$ & Cd(II) \\
\hline El- & S1 & 9.99 & 0.0043 & 0.0067 & 23.2 & 8.5 & 52.1 & 90.2 & 98.3 & 96.8 \\
\hline \multirow[t]{3}{*}{ Sharkia } & $\mathbf{S 2}$ & 4.42 & 0.0054 & 0.0045 & 24.7 & 9.1 & 27.3 & 91.0 & 98.1 & 97.2 \\
\hline & $\mathbf{S 3}$ & 1.45 & 0.0048 & 0.0035 & 26.1 & 8.9 & 27.0 & 90.5 & 98.5 & 96.5 \\
\hline & F1 & 4.45 & 0.098 & 0.0042 & 30.4 & 9.4 & 42.5 & 89.5 & 98.7 & 96.2 \\
\hline El- & F2 & 2.55 & 0.0054 & 0.0023 & 32.2 & 8.5 & 33.1 & 90.2 & 98.3 & 97.4 \\
\hline \multirow[t]{2}{*}{ Fayium } & F3 & 1.68 & 0.0151 & 0.0021 & 25.2 & 10.1 & 26.5 & 91.2 & 97.2 & 97.8 \\
\hline & M1 & 4.57 & 12.7 & 1.11 & 101.5 & 38 & 63.5 & 89.6 & 96.5 & 95.0 \\
\hline El- & M2 & 4.42 & 3.02 & 1.61 & 111.2 & 44 & 59.6 & 89.9 & 97.1 & 97.0 \\
\hline Monofia & M3 & 1.25 & 0.051 & 0.015 & 37.5 & 10.5 & 29.1 & 91.2 & 96.5 & 96.8 \\
\hline
\end{tabular}

S1:Sharkia site 1, S2: Sharkia site 2, S3: Sharkia site 3, M1: Menofia site 1, M2: Menofia site 2, M3:

Menofia site 3, F1: Fayium site 1, F2: Fayium site 2, F3: Fayium site 3.

\section{CONCLUSION}

In this study, hematite@ chitosan core/organically shell nanocomposite (HCS) was synthesized. It is a novel, recyclable, chemically and thermodynamically stable, low cost, environmentally-friendly material, low biological toxicity, biodegradable 
and safe adsorbent. This adsorbent was used in $\mathrm{Pb}^{2+}, \mathrm{Cd}^{2+}$ and $\mathrm{Cu}^{2+}$ removal from industrial wastewater many times with high regeneration capacity and stability.

\section{RECOMMENDATION}

It is recommended to use the fabricated HCS nanocomposite in heavy metals removal from industrial wastewater especially for $\mathrm{Pb}^{2+}, \mathrm{Cd}^{2+}$ and $\mathrm{Cu}^{2+}$ metal ions.

\section{REFERENCES}

Abd El-Fattah, M.; El Saeed, A. M.; Azzam, A. M.; Abdul-Raheim, A. M. and Hefni, H. H. H. (2016). Improvement of corrosion resistance, antimicrobial activity, mechanical and chemical properties of epoxy coating by loading chitosan as a natural renewable resource. Prog. Organ. Coat., 101: 288.

Abdel-Mohsien, H. S. and Mahmoud, M. A. M. (2015). Accumulation of Some Heavy Metals in Oreochromis niloticus from the Nile in Egypt: Potential Hazards to Fish and Consumers. J. Environ. Protection, 6:1003-1013.

Abdulkadir, I. and Aliyu, A. B. (2013). Some wet routes for synthesis of hematite nanostructures. African Journal of Pure and Applied Chemistry, 7(3): 114-121.

Abou El Fadl, F. I. (2014). Radiation grafting of ionically crosslinked alginate/chitosan beads with acrylic acid for lead sorption. J. Radioanal. Nucl. Chem., 301: 529-535.

Agrawal, A. and Sahu, K. K. (2006). Kinetic and isotherm studies of cadmium adsorption on manganese nodule residue. J. Hazard. Mater., 137: 915-924.

Beidokhti, H. R. N.; Ghaffarzadegan, R.; Mirzakhanlouei, S.; Ghazizadeh, L. and Dorkoosh, F. A. (2017). Preparation, Characterization, and Optimization of Folic Acid-Chitosan-Methotrexate Core-Shell Nanoparticles by Box-Behnken Design for Tumor-Targeted Drug Delivery. AAPS Pharm. Sci. Tech., 18: 115.

Broujeni, B. R.; Nilchi, A.; Hassani, A. H. and Saberi, R. (2018). Preparation and characterization of chitosan/ $\mathrm{Fe}_{2} \mathrm{O}_{3}$ nano composite for the adsorption of thorium (IV) ion from aqueous solution. Water Science \& Technology, 78 (3): 708-720.

Cabanas-Polo, S.; Distaso, M.; Peukert, W. and Boccaccini, A. R. (2015). Electrophoretic Deposition of $\alpha-\mathrm{Fe}_{2} \mathrm{O}_{3} /$ Chitosan Nanocomposite Coatings for Functional and Biomedical Applications. Journal of Nanoscience and Nanotechnology, 15:10149-10155.

Charpentier, T. V. J.; Neville, A.; Lanigan, J. L.; Barker, R.; Smith, M. J.; Richardson, T. (2016). Preparation of Magnetic Carboxymethylchitosan Nanoparticles for Adsorption of Heavy Metal Ions. ACS Omega, 1(1): 77-83.

Chen, B.; Zhao, H.; Chen, S.; Long, F.; Huang, B.; Yang, B. and Pan, X. (2019). A magnetically recyclable chitosan composite adsorbent functionalized with EDTA for simultaneous capture of anionic dye and heavy metals in complex wastewater. Chemical Engineering Journal, 356: 69-80.

Chen, C. and Wang, J. L. (2008). Removal of $\mathrm{Pb}^{2+}, \mathrm{Ag}$, Cs and $\mathrm{Sr}^{2+}$ from aqueous solution by brewery's waste biomass. J. Hazard. Mater., 151: 65-70.

Chen, Y. H. and Li, F. A. (2010). Kinetic study on removal of copper(II) using goethite and hematite nano-photocatalysts. J. Colloid. Interf. Sci., 347: 277281. 
Chiban, M.; Carja, G.; Lehutu, G. and Sinan, F. (2016). Equilibrium and thermodynamic studies for the removal of $\mathrm{As}(\mathrm{V})$ ions from aqueous solution using dried plants as adsorbents. Arab J. Chem., 9: 5988-5999.

Chibuike, G. U. and Obiora, S. C. (2014). Heavy metal polluted soils: Effect on plants and bioremediation methods. Applied and Environmental Soil Science., 2014: 1-12.

De Queiroz Antonino, R. S. C. M.; Lia Fook , B. R. P.; de Oliveira Lima, V. A.; De Farias Rached, R. Í.; Lima, E. P. N.; Da Silva Lima, R. J.; Peniche Covas, C. A. and Lia Fook, M. V. (2017). Preparation and Characterization of Chitosan Obtained from Shells of Shrimp (Litopenaeus vannamei Boone). Mar Drugs., 15(5): 141-152.

Deliyanni , E. A.; Peleka, E. N. and Matis, K. A. (2009). Modeling the sorption of metal ions from aqueous solution by iron-based adsorbents. J. Hazard Mater., 172: $550-558$.

Dong, L.; Wen, C.; Junxia, Y. and Yigang, D. (2017). Polyamine chitosan adsorbent for the enhanced adsorption of anionic dyes from water. Water Sci. Technol., 18:1832-1841.

Farzana, M. H. and Meenakshi, S. (2015). Photocatalytic aptitude of titanium dioxide impregnated chitosan beads for the reduction of $\mathrm{Cr}(\mathrm{VI})$. International Journal of Biological Macromolecules, 72: 1265-1271.

Febrianto, J.; Kosasih, A. N.; Sunarso, J.; Ju, Y. H.; Indraswati, N.; Ismadji, S. (2009). Equilibrium and kinetic studies in adsorption of heavy metals using biosorbent: asummary of recent studies. J. Hazard. Mater., 162: 616-645.

Freundlich, H. M. F. (1906). Uber Die Adsorption in Lasungen. Journal of Physical Chemistry, 57: 385-370.

Fu, F. and Wang, Q. (2011). Removal of heavy metal ions from wastewaters: A review. Journal of Environmental Management, 92: 407-418.

Gebrekidan, M. and Samuel, Z. (2011). Concentration of Heavy Metals in Drinking Water from Urban Areas of the Tigray Region, Northern Ethiopia. MEJS, 3(1):105-121.

Gupta, V. (2013). Mammalian Feces as Bio-Indicator of Heavy Metal Contamination in Bikaner Zoological Garden, Rajasthan, India. Res. J. Animal, Veterinary and Fishery Sci., 1(5): 10-15.

Gupta, V. K. and Nayak, A. (2012). Cadmium removal and recovery from aqueous solutions by novel adsorbents prepared from orange peel and $\mathrm{Fe}_{2} \mathrm{O}_{3}$ nanoparticles. Chemical Engineering Journal, 180: 81-90.

Gupta, V. K.; Rastogi, A. and Nayak, A. (2010), Adsorption studies on the removal of hexavalent chromium from aqueous solution using a low cost fertilizer industry waste material. Journal of Colloid and Interface Science, 342: 135-141.

Han, D. Y.; Jiang, X and Xie, C. S. (2006). Preparation and adsorption property for metal ions of crosslinked chitosan magnetic microspheres. Environ. Chem., 25: 748-751.

Hao, Y. M.; Chen, M. and Hu, Z. B. (2010). Effective removal of $\mathrm{Cu}$ (II) ions from aqueous solution by amino-functionalized magnetic nanoparticles. J. Hazard Mater., 184: 392-399.

Hassan, H. E.; Abdel Rahman ,A. A.; El-Sherbini, E. A.; Tawfic, T. A. and Abdel Tawab, A. R. (2012). Phytoremediation of Industrial Wastewater Polluted with Heavy Metals Using Water Hyacinth Roots. Journal of Applied Sciences Research, 8(8): 3878-3886. 
Huang, C. L.; Zhang, H. Y.; Sun, Z. Y. and Liu, Z. M. (2010). Chitosan-mediated synthesis of mesoporous $\alpha-\mathrm{Fe}_{2} \mathrm{O}_{3}$ nanoparticles and their applications in catalyzing selective oxidation of cyclohexane. Sci. China Chem., 53(7): 15021508.

Huang, J.; Ye, M.; Qu, Y.; Chu, L.; Chen, R.; He, Q. and Xu, D.(2012). Pb (II) removal from aqueous media by EDTA-modified mesoporous silica SBA-15. J. Colloid Interface Sci., 385: 137-146.

Huang, K. S.; Yang, C. H.; Huang, S. L.; Chen, C. U.; Lu, Y. Y. and Lin, Y. S. (2016). Recent Advances in Antimicrobial Polymers: A Mini-Review. Int. J. Mol. Sci., 17(9): 1578-1591.

Jiang, Y.; Wang, W. N.; Biswas, P. and Fortner, J. D. (2014). Facile Aerosol Synthesis and Characterization of Ternary Crumpled Graphene- $\mathrm{TiO}_{2}-$ Magnetite Nanocomposites for Advanced Water Treatment. ACS Appl. Mater. Interface, 6(4): 11766-11774.

Kandile, N. G.; Mohamed, H. M. and Mohamed, M. I. (2015). New heterocycle modified chitosan adsorbent for metal ions (II) removal from aqueous systems. International Journal of Biological Macromolecules, 72: 110-116.

Keshvardoostchokami, M.; Babaei, L.; Zamani, A. A.; Parizanganeh, A. H. and Piri, F. (2017). Synthesized chitosan/ iron oxide nanocomposite and shrimp shell in removal of nickel, cadmium and lead from aqueous solution. Global J. Environ. Sci. Manage., 3(3): 267-278.

Khan, S. A.; Din, Z. U.; Ihsanullah and Zubair, A. (2011). Levels of selected heavy metals in drinking water of Peshawar city. I.J.S.N., 2(3): 648-652.

Langmuir, I. (1916). The Constitution and Fundamental Properties of Solids and Liquids. Part I. Solids. Journal of the American Chemical Society, 38: 22212295.

Langston, W. J.; Burt, G. R. and Pope, N. D. (1999). Bioavailability of metals in sediments of the dogger bank (Central North Sea): A mesocosm study. Estuarine. Coastal and Shelf Science, 48: 519-540.

Lasheen, M. R.; El-Sherif, I. Y.; Sabry, D. Y.; El-Wakeel, S. T. and El-Shahat, M. F. (2014). Removal and recovery of $\mathrm{Cr}(\mathrm{VI})$ by magnetite nanoparticle. Desalin. Water Treat., 52: 6464-6473.

Lasheen, M. R.; El-Sherif, I. Y.; Tawfik, M. E.; El-Wakeel, S. T.; El-Shahat, M. F. (2016). Preparation and adsorption properties of nano magnetite chitosan films for heavy metal ions from aqueous solution. Materials Research Bulletin, 80: 344-350.

Laus, R. and De Fávere, V. T. (2011). Competitive adsorption of Cu (II) and Cd (II) ions by chitosan crosslinked with epichlorohydrin-triphosphate - Bioresource. Technol., 102: 8769.

Lenntech, B. V. (2012). Heavy Metals, Available at Website: www.lenntech.co./periodic.periodic-chart.htm

Lin, K.; Pan, J.; Chen, Y.; Cheng, R. and Xu, X. (2009). Study the adsorption of phenol from aqueous solution on hydroxyapatite nanopowders. J. Hazard. Mater., 161: 231-240.

Liu, Y.; Cao, X.; Hua, R.; Wang, Y.; Liu, Y.; Pang, C. and Wang, Y.(2010). Entrapment of nanoscale zero-valent iron in chitosan beads for hexavalent chromium removal from wastewater. Journal of Hazardous Materials, 184: 724730 . 
Liu, X. W.; Hu, Q. Y.; Fang, Z.; Zhang, X. J. and Zhang, B. B. (2009). Magnetic Chitosan Nanocomposites: A Useful Recyclable Tool for Heavy Metal Ion Removal. Langmuir, 25: 3.

Ma, X. F.; Zhang, B.; Cong, Q.; He, X. C.; Gao, M. J. and Li, G. (2016). Improved multi-shot diffusion imaging using GRAPPA with a compact kernel. Mater. Chem. Phys., 178: 88.

Mandavian, A. R. and Mirrahimi, M. A. S. (2010). Efficient separation of heavy metal cations by anchoring polyacrylic acid on superparamagnetic magnetite nanoparticles through surface modification. Chem. Eng. J., 159: 264-271.

Mishra, S. P.; Singh, V. K. and Tiwari, D. (1996). Radiotracer technique in adsorption study: Part XIV. Efficient removal of mercury from aqueous solutions by hydrous zirconium oxide. Applied Radiation and Isotopes, 15: 21.

Pan, B.; Pan, B.; Zhang, W.; Lv, L.; Zhang, Q. and Zheng, S. (2009). Development of polymeric and polymer-based hybrid adsorbents for pollutants removal from waters. Chemical Engineering Journal, 151: 19-29.

Parveen, Z.; Khuhro, M. I. and Rafiq, N. (2003). Market basket survey for lead, cadmium, copper, chromium, nickel and zinc in fruits and vegetables. Bulletin of Environmental Toxicology, 71: 1260-1264.

Rahmani, A; Mosavi, H. Z. and Fazli, M (2010). Effect of nanostructure alumina on adsorption of heavy metals. Desalination, 253: 94-100.

Rafi, M. M.; Ahmed, K. S. Z.; Nazeer, K. P.; Kumar, D. S. and Thamilselvan, M. (2015). Synthesis, characterization and magnetic properties of hematite (a$\mathrm{Fe}_{2} \mathrm{O}_{3}$ ) nanoparticles on polysaccharide templates and their antibacterial activity. Appl Nanosci, 5:515-520.

Shahzad, A.; Miran, W.; Rasool, K.; Nawaz, M.; Jang, J.; Lim, S. R. and Lee, D. S. (2017). Heavy metals removal by EDTA-functionalizedchitosan graphene oxide nanocomposites. RSC Adv., 7: 9764-9771.

Shekhawat, A.; Kahu, S.; Saravanan, D. and Jugade, R. (2017). Removal of Cd(II) and $\mathrm{Hg}(\mathrm{II})$ from effluents by ionic solid impregnated chitosan. Int. J. Biol. Macromol. 104: 1556-1568.

Singh, J.; Srivastavab, M.; Duttac, J. and Dutta, P. K. (2011a). Preparation and properties of hybrid monodispersed magnetic $\alpha-\mathrm{Fe}_{2} \mathrm{O}_{3}$ based chitosan nanocomposite film for industrial and biomedical applications. International Journal of Biological Macromolecules, 48: 170-176.

Singh, S.; Lal, S.; Harjit, J.; Amlathe, S. and Kataria, H. C. (2011b). Potential of Metal Extractants in Determination of Trace Metals in Water Sample. Advanced Studies in Biology, 3(5): 239-246.

Srivastava, M.; Ojha, A. K.; Chaubey, S.; Singh, J.; Sharma, K. P.; Pandey, C. A. and Alloys, J. (2010). Investigation on magnetic properties of nanoparticles synthesized under surfactant-free condition by hydrothermal process. Compd., 500:206-210.

Sun, J. M.; Zhu, W. T. and Huang, J. C. (2006). Characterization of primary precipitate composition formed during co-removal of $\mathrm{Cr}$ (VI) with $\mathrm{Cu}$ (II) in synthetic wastewater. Environ. Sci. Pollut. Res. Int., 13: 379.

Taghipour, H. and Mosaferi, M. (2013). Heavy metals in the vegetables collected from production sites. Health Promot Perspect., 3(2): 185-93.

Thinh, N. N.; Hanh, P. T. B; Ha, L. T. T; Anh, L. N; Hoang, T. V. ; Hoang, V. D; Khoi, N. V. and Lam, T. D. (2013). Magnetic Chitosan Nanoparticles for Removal of $\mathrm{Cr}(\mathrm{VI})$ from Aqueous Solution, Material Science and Engineering., 33: $1214-1218$. 
Tian, H.; Zhang, Q.; Li, H. and Zhang, G. (2003). Antioxidant N-acetylcysteine and AMPA/KA receptor antagonist DNQX inhibited mixed lineage kinase-3 activation following cerebral ischemia in rat hippocampus. Neuroscience Research, 47: 47-53.

Zaidi, M. I; Asrar, A.; Mansoor, A. and Farooqui, M. A. (2005). The heavy metal concentrations along Road side trees of Quetta and its effects on public health. Journal of Applied Science, 5: 708-711.

Zhao, F.; Yu, B., Yue, Z.; Wang, T.; Wen, X.; Liu, Z. and Zhao, C. (2007). Preparation of porous chitosan gel beads for copper (II) ion adsorption. J. Hazard. Mater., 147: 67-73.

Zhou, Y. T.; Nie, H. L.; Branford-White, C.; He, Z. Y. and Zhu, L. M. (2009). Removal of $\mathrm{Cu}^{2+}$ from aqueous solution by chitosan-coated magnetic nanoparticles modified with $\alpha$-ketoglutaric acid. Journal of Colloid and Interface Science, 330: 29-37.

Zhao, G.; Wu, X.; Tan, X. and Wang, X. (2011). Sorption of heavy metal ions from aqueous solutions: A review. Open Colloid Sci. J., 4:19-31.

\section{ARABIC SUMMARY}

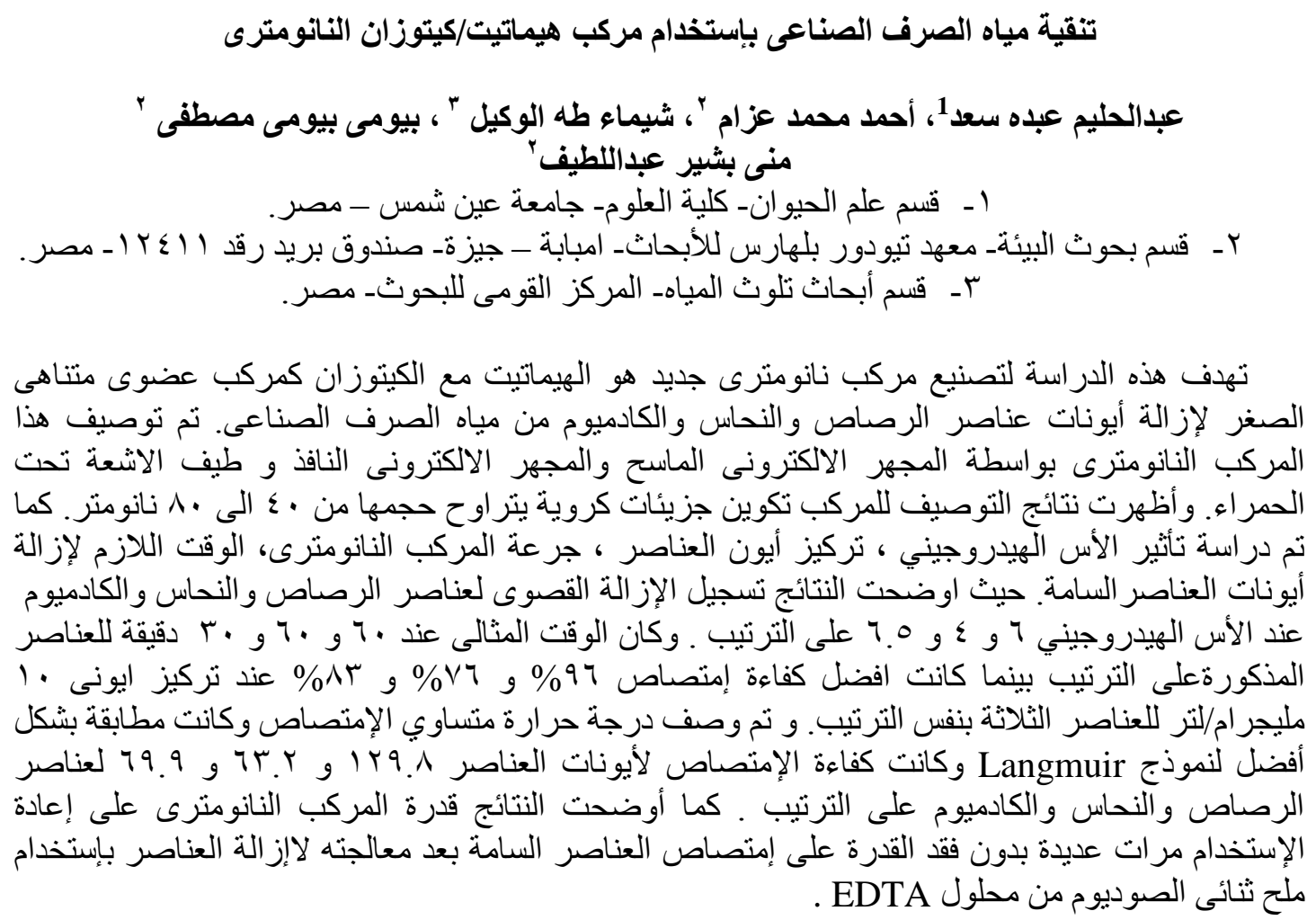

